\title{
Experimental and modeling study of the gasoline HCCI engine with internal gas recirculation
}

\begin{abstract}
In this study experimental and modeling investigations of a gasoline HCCI engine with internal gas recirculation have been presented. Experimental measurements enabled identification of attainable range of valvetrain settings and air excess coefficient that allows a realization of the HCCI combustion. Factors determining the charge exchange process and the resulting in-cylinder temperature were specified based on computational analysis.
\end{abstract}

Key words: HCCI, variable valve timing, negative valve overlap, charge exchange

\section{Badania eksperymentalne i modelowe procesu roboczego benzynowego silnika HCCI z wewnętrzną recyrkulacją spalin}

\begin{abstract}
W pracy przedstawiono wyniki badań eksperymentalnych i modelowych procesu roboczego benzynowego silnika HCCI $z$ wewnętrzna recyrkulacja spalin. Na podstawie wyników badań eksperymentalnych określono zakres faz rozrządu oraz współczynnika nadmiaru powietrza, w którym możliwa jest realizacja procesu HCCI. Przeprowadzone badania symulacyjne pozwolity na zidentyfikowanie czynników ksztattujących przebieg wymiany tadunku oraz temperaturę w cylindrze.

Słowa kluczowe: silnik HCCI, zmienne fazy rozrzadu, ujemne współotwarcie zaworów, wymiana ładunku
\end{abstract}

\section{Introduction}

A combustion system using HCCI (homogeneous charge compression ignition) is a combination of two known ways of realization of processes used in spark ignition and compression ignition engines. An engine operating in the HCCI mode is distinguished by the fact that combustion is initiated in numerous places of the working space at the same time $[5,8]$. Therefore, there is no flame front propagation and temperature and the entire working space of the cylinder may be treated as homogenous. Maximum temperature values are much lower than in traditional combustion systems. This is the result of one of the main advantages of HCCI combustion, namely a much lower emission of nitric oxides. Moreover, considerable heat release rate in the cylinder allows an increase in the thermal efficiency as compared to spark ignition engines [6].

In order to obtain a temperature necessary for selfignition of the mixture in the cylinder it is necessary to supply additional energy to the working medium. In initial experiments related to HCCI engines, energy of the working medium was increased by heating of the intake air. Often the compression ratio was also increased [4]. However, such solutions are not suitable for use in vehicle engines. Another method, which may be used in traditional engines, involves supplying of additional energy to the cylinder by internal gas recirculation. In this case, the technique of negative valve overlap is applied.

Despite the fact that negative valve overlap is a promising method of realization of HCCI combustion, it is possible to obtain the engine operation only for small and medium loads with the use of this method. [9]. Considerable dilution of load in the cylinder by internally recirculated gas and

\section{Wstęp}

System spalania wykorzystujący samoczynny zapłon mieszanki jednorodnej HCCI (ang. homogeneous charge compression ignition) jest połączeniem dwóch znanych sposobów realizacji procesów roboczych stosowanych $\mathrm{w}$ silnikach o zapłonie iskrowym oraz o zapłonie samoczynnym. Silnik pracujący w trybie HCCI wyróżnia się tym, że inicjacja spalania występuje $\mathrm{w}$ wielu miejscach przestrzeni roboczej jednocześnie [5, 8]. Dzięki temu nie występuje propagacja frontu płomienia, a temperaturę w całej przestrzeni roboczej cylindra można traktować jako jednorodną. Jej maksymalne wartości są znacznie mniejsze niż w tradycyjnych systemach spalania. Z tego wynika jedna z głównych zalet systemu spalania HCCI, którą jest znacznie niższa emisja tlenków azotu. Ponadto znaczna szybkość wywiązywania się ciepła w cylindrze pozwala na zwiększenie sprawności cieplnej w porównaniu do silników o zapłonie iskrowym [6].

W celu uzyskania temperatury potrzebnej do samozapłonu mieszanki w cylindrze konieczne jest dostarczenie dodatkowej energii do czynnika roboczego. W pierwszych eksperymentach dotyczących silników HCCI energię czynnika roboczego zwiększano przez podgrzewanie zasysanego powietrza. Często także dodatkowo zwiększano stopień sprężania [4]. Jednak takie rozwiązania nie nadają się do zastosowania w silnikach samochodowych. Inną metodą, która może być wykorzystana w silnikach trakcyjnych jest doprowadzenie dodatkowej energii do cylindra przez wewnętrzną recyrkulację spalin. Wtedy stosuje się technikę tzw. ujemnego współotwarcia zaworów.

Pomimo iż ujemne współotwarcie zaworów jest obiecującym sposobem realizacji systemu spalania HCCI, za pomocą tej metody można uzyskać pracę silnika tylko w 
high temperature values during the period of intake process lead to a decrease in the filling coefficient. Limitation of the upper range of the engine load also results from admissible pressure increment rate inside the cylinder [7].

The course of charge exchange process in HCCI working with negative valve overlap, is considerably different from that realized in typical 4-stroke engines. In typical engines during the period of valve overlap, pressure values in the cylinder as well as intake and exhaust manifolds aim to equalize. It is only due to the inertia of the flowing medium and fluid column vibrations in the intake and exhaust ducts that the equilibrium is incomplete. In case of an engine with internal gas recirculation, the equilibrium does not exist. The exhaust valve is closed several dozen degrees C.A. before TDC and the intake valve is opened with an appropriate delay. Higher flow resistances connected with lower valve lift and valve opening angles are compensated by opening of a throttle.

Valve timings constitute the main instruments allowing a volumetric efficiency and exhaust gas recirculation rate. Therefore, identification of charge transport processes is an extremely important issue from the point of view of the organization of the combustion process. Enthalpy of exhaust gas obtained in the cylinder increases the temperature of the working medium as of closing of the intake valve to enable self-ignition of the fuel-air mixture in the final stage of the compression process. Thermodynamic parameters of the internally recirculated gas determine the volume of air that gets into the cylinder.

Within the entire attainable range of load, there is a state of equilibrium between thermodynamic parameters of the intake medium and the exhaust medium leaving the cylinder. The volumetric efficiency rate, exhaust gas emperature and exhaust gas recirculation rate are closely connected with one another and the total mass of charge in the cylinder changes within low limits [2]. For settings of the valve system allowing an autonomous operation of the engine in the HCCI mode (without the need to use spark discharge) thermodynamic processes connected with charge exchange guarantee maintaining of an appropriate course of compression temperature curve, regardless of the air excess coefficient and volumetric efficiency rate.

This study presents results of experimental and model tests of the operating process of HCCI gasoline fueled engine. The aim of the model tests was to explain reasons for change of an angle of mixture self-ignition with variable adjustment parameters and identification of the engine operation range.

\section{Research stand}

Tests were conducted on a single-cylinder SB 3.5 test engine. The main engine data have been presented in table 1 . All settings for the intake and exhaust valve may be changed during the engine operation regardless of each other. A variable valve lift was attained owing to a hydraulic mechanism fitted in the test engine as described in detail in the studies $[2,3]$. The test engine has a combustion chamber in the form of a sphere located in the head. The piston bottom in TDC zakresie małych i średnich obciążeń [9]. Znaczne rozcieńczenie ładunku w cylindrze przez wewnętrznie recyrkulowane spaliny oraz duże wartości temperatury podczas procesu dolotu prowadzą do obniżenia współczynnika napełnienia. Ograniczenie górnego zakresu obciążenia silnika wynika także z dopuszczalnej szybkości narastania ciśnienia w cylindrze [7].

Przebieg procesu wymiany ładunku w silniku HCCI, pracującym z ujemnym współotwarciem zaworów, znacząco różni się od tych, realizowanych w klasycznych silnikach 4-suwowych. W typowych silnikach w okresie współotwarcia zaworów wartości ciśnienia w cylindrze oraz kolektorach dolotowym i wylotowym dążą do wyrównania. Jedynie ze względu na bezwładność przepływającego czynnika oraz drgania słupa płynu w przewodach dolotowym i wylotowym równowaga ta nie jest całkowita. $\mathrm{W}$ silniku $\mathrm{z}$ wewnętrzną recyrkulacją spalin taka równowaga nie istnieje. Zawór wylotowy zamykany jest kilkadziesiąt stopni OWK przed GMP, a zawór dolotowy otwierany jest $\mathrm{z}$ odpowiednim opóźnieniem. Związane z mniejszymi wzniosami i kątami otwarcia zaworów większe opory przepływu kompensowane są przez otwarcie przepustnicy.

Fazy rozrządu stanowią główny instrument umożliwiający regulację napełnienia cylindra i współczynnika reszty spalin, dlatego identyfikacja procesów transportu ładunku jest niezwykle ważnym zagadnieniem z punktu widzenia organizacji procesu spalania. Entalpia zatrzymanych w cylindrze spalin zwiększa temperaturę czynnika roboczego w chwili zamknięcia zaworu dolotowego, aby w końcowym etapie procesu sprężania umożliwić samozapłon mieszanki paliwowo-powietrznej. Parametry termodynamiczne recyrkulowanych wewnętrznie spalin determinują ilość powietrza, która dostaje się do cylindra.

W całym osiągalnym zakresie obciążenia występuje pewien stan równowagi pomiędzy parametrami termodynamicznymi zasysanego czynnika i opuszczającego cylinder. Współczynnik napełnienia cylindra, temperatura spalin i współczynnik recyrkulacji spalin są ze sobą ściśle związane, a łączna masa ładunku w cylindrze zmienia się w niewielkich granicach [2]. Przy nastawach układu rozrządu pozwalających na autonomiczną pracę silnika w trybie HCCI (bez konieczności stosowania wyładowania iskrowego) procesy termodynamiczne związane z wymianą ładunku gwarantują utrzymanie właściwego przebiegu krzywej temperatury sprężania, niezależnie od współczynnika nadmiaru powietrza i napełnienia cylindra.

W niniejszej pracy przedstawiono wyniki badań eksperymentalnych i modelowych procesu roboczego silnika HCCI zasilanego benzyną. Celem badań modelowych było wyjaśnienie przyczyn zmian kąta samozapłonu mieszanki przy zmiennych parametrach regulacyjnych oraz identyfikacja zakresu pracy silnika.

\section{Stanowisko badawcze}

Badania przeprowadzono na jednocylindrowym silniku badawczym SB 3.5. Główne dane silnika zestawiono w tabeli 1. Wszystkie nastawy dla zaworu dolotowego i wylotowego mogą być zmieniane podczas pracy silnika niezależnie od 
protrudes considerably over the dividing plane of the engine cylinder and head approaching the combustion chamber walls in the head on the circumference. This structure of the combustion chamber leads to swirls in the working space as a result of the pushout effect.

A HDEV type electromagnetic fuel injector manufactured by $\mathrm{BOSCH}$ was inserted in the head. It feeds fuel directly to the combustion chamber. The fuel spray is injected statically in relation to the direction of swirl caused by the shape of the intake. The detailed description of the combustion chamber is specified in the study [1].

The engine was installed at a stand used for dynamometric tests fitted with a DC machine. The engine control system was based on a real time PC controlled microprocessor module. The injection and ignition module were designed to enable an accurate and recurrent control of the fuel dose, injection and ignition angles.

Table 1. Specifications of SB 3.5 test engine

Tabela 1. Specyfikacja silnika badawczego SB 3.5

\begin{tabular}{|l|c|}
\hline Displacement/objętość skokowa & $498.5 \mathrm{~cm}^{3}$ \\
\hline Cylinder bore/srednica cylindra & $84 \mathrm{~mm}$ \\
\hline Piston stroke/skok tłoka & $90 \mathrm{~mm}$ \\
\hline Compression ratio/stopień sprężania & 11.7 \\
\hline Number of valves/liczba zaworów & 2 \\
\hline $\begin{array}{l}\text { Total opening angle of the intake valve/całko- } \\
\text { wity kąt otwarcia zaworu dolotowego }\end{array}$ & $120 \ldots 235^{\circ}$ C.A. \\
\hline Intake valve lift/wznios zaworu dolotowego & $2.4 \ldots 9.4 \mathrm{~mm}$ \\
\hline $\begin{array}{l}\text { Total opening angle of the exhaust valve/całko- } \\
\text { wity kąt otwarcia zaworu wylotowego }\end{array}$ & $120 \ldots .235^{\circ} \mathrm{C} . \mathrm{A}$. \\
\hline Exhaust valve lift/wznios zaworu wylotowego & $2.2 \ldots 9.2 \mathrm{~mm}$ \\
\hline Fuel injector/wtryskiwacz paliwa & $\begin{array}{r}\text { electromagnetic, swirl/ } \\
\text { elektromagnetyczny, wirowy }\end{array}$ \\
\hline
\end{tabular}

\section{Test conditions}

The tests were conducted for the engine speed of 1500 rpm and maximum throttle opening. The engine was fueled with 95-octane commercial gasoline from a single supplier. The fuel pressure measured in the common rail equaled 10 $\mathrm{MPa}$. The valve lifts were reduced to $3.6 \mathrm{~mm}$ for the intake valve and to $2.9 \mathrm{~mm}$ for the exhaust valve in order to realize negative valve overlap. The tests were conducted for four valve timing positions ensuring various angles of negative valve overlap and variable exhaust gas recirculation rate. The air excess coefficient was changed within the entire range allowing autonomous operation of the engine in the HCCI mode, i.e. without supporting the ignition with a spark discharge. The fuel was supplied to the cylinder during the negative valve overlap and during exhaust gas decompression in order to ensure a homogenous mixture of air and fuel in the cylinder. The mass of the exhaust gas retained in the cylinder was calculated with the use of equation of state of an ideal gas based on its volume, pressure and temperature as of closing of the exhaust valve. In order to avoid errors when measuring the pressure signal as caused by vibration during closing of the exhaust valve, the valve closing pres- siebie. Zmienny wznios zaworów został osiągnięty dzięki wyposażeniu silnika badawczego w hydrauliczny mechanizm, który szczegółowo opisano w pracach [2, 3]. Silnik badawczy posiada komorę spalania w kształcie odcinka kuli umieszczoną w głowicy. Denko tłoka w GMP znacznie wystaje ponad płaszczyznę podziału cylindra i głowicy silnika, zbliżając się na obwodzie do ścianek komory spalania w głowicy. Taka konstrukcja komory spalania powoduje powstawanie zawirowań przestrzeni roboczej w wyniku efektu wyciskania.

W głowicy umieszczono elektromagnetyczny wtryskiwacz paliwa firmy BOSCH typu HDEV, który podaje paliwo bezpośrednio do komory spalania. Struga paliwa wtryskiwana jest stycznie do kierunku zawirowania wywołanego przez kształt kanału dolotowego. Szczegółowy opis konstrukcji komory spalania zawarto w pracy [1].

Silnik zainstalowano na stanowisku do badań dynamometrycznych wyposażonym w maszynę prądu stałego. Układ sterowania silnikiem oparty został na mikroprocesorowym module czasu rzeczywistego, zarządzanym przez komputer osobisty. Moduł wtrysku i zapłonu zaprojektowano w taki sposób, aby umożliwić precyzyjne i powtarzalne sterowanie dawką paliwa oraz kątem początku wtrysku i kątem zapłonu.

\section{Warunki badań}

Badania przeprowadzono przy prędkości obrotowej wału korbowego równej 1500 obr/min i całkowicie otwartej przepustnicy. Silnik zasilany był benzyną handlową o badawczej liczbie oktanowej 95, pochodzącą z jednej dostawy. Ciśnienie paliwa mierzone w szynie paliwowej było równe $10 \mathrm{MPa}$. Wzniosy zaworów zostały zredukowane do 3,6 mm dla zaworu dolotowego i $2,9 \mathrm{~mm}$ dla zaworu wylotowego w celu realizacji ujemnego współotwarcia zaworów. Badania przeprowadzono dla czterech ustawień rozrządu zapewniających różne kąty ujemnego współotwarcia zaworów oraz zmienny współczynnik recyrkulacji spalin. Współczynnik nadmiaru powietrza zmieniany był w całym zakresie pozwalającym na autonomiczną prace silnika w trybie HCCI, tzn. bez wspomagania zapłonu wyładowaniem iskrowym. Paliwo podawane było do cylindra w czasie ujemnego współotwarcia zaworów podczas rozprężania spalin, aby zapewnić jednorodną mieszankę paliwowo-powietrzną w cylindrze. Masa zatrzymanych spalin w cylindrze była obliczana $\mathrm{z}$ równania stanu gazu doskonałego na podstawie objętości, ciśnienia i temperatury w chwili zamykania zaworu wylotowego. W celu uniknięcia błędów przy pomiarze sygnału ciśnienia spowodowanych drganiami podczas zamykania zaworu wylotowego, ciśnienie zamknięcia zaworu obliczane było przy wykorzystaniu modelu politropowego sprężania. Temperatura spalin mierzona była za pomocą termopary umieszczonej w pobliżu zaworu wylotowego. Współczynnik recyrkulacji spalin obliczano jako stosunek masy spalin i całkowitej masy ładunku w cylindrze. Masa zasysanego powietrza mierzona była za pomocą przepływomierza termoanemometrycznego. Zużycie paliwa 
sure was calculated with the use of a polytrophic compression module. Exhaust gas temperature was measured with the use of a thermocouple located near the exhaust valve. Exhaust gas recirculation rate was calculated as a relation of exhaust gas mass to the total mass of charge in the cylinder. The mass of the intake air was measured with the use of a thermoanemometric flow meter. Fuel consumption was measured with the use of a gravimetric method with the measurement time of $30 \mathrm{~s}$.

\section{Test results}

Figure 1 presents the attainable engine operation range for variable valve timings and variable air excess coefficient. Limitations of the range of exhaust gas recirculation rate (EGR) and air excess coefficient ( $\lambda$ ) result from the composition of charge in the cylinder and its thermodynamic properties. The maximum volume of fuel retained in the cylinder is limited by the volume of water and carbon dioxide. However, with increase of the air excess coefficient, concentration of the above-mentioned components of the exhaust gas changes. Therefore, the leaner the mixture, the greater mass of exhaust gas may be retained in the cylinder. The lowest values of exhaust gas recirculation rate result from the need to supply appropriate amount of heat to the combustion chamber, which limits the volume of air in the cylinder and decreases attainable loads of the engine. The lowest load values attained amounted to $0.15 \mathrm{MPa}$ of mean indicated pressure. It was not possible to decrease pressure any further due to fuel dilution and an increase of variability ratio of the mean indicated pressure (Fig. 2).

The angle of combustion of $5 \%$ of the fuel dose has been presented in Fig. 3. The earliest start of combustion was observed for a slightly lean fuel-air mixture and moderate exhaust gas recirculation rate. Both the increase and the decrease of the exhaust gas volumes retained in the cylinder caused a delay of combustion. It is obvious that changes of self-ignition angle are connected with the changes in the

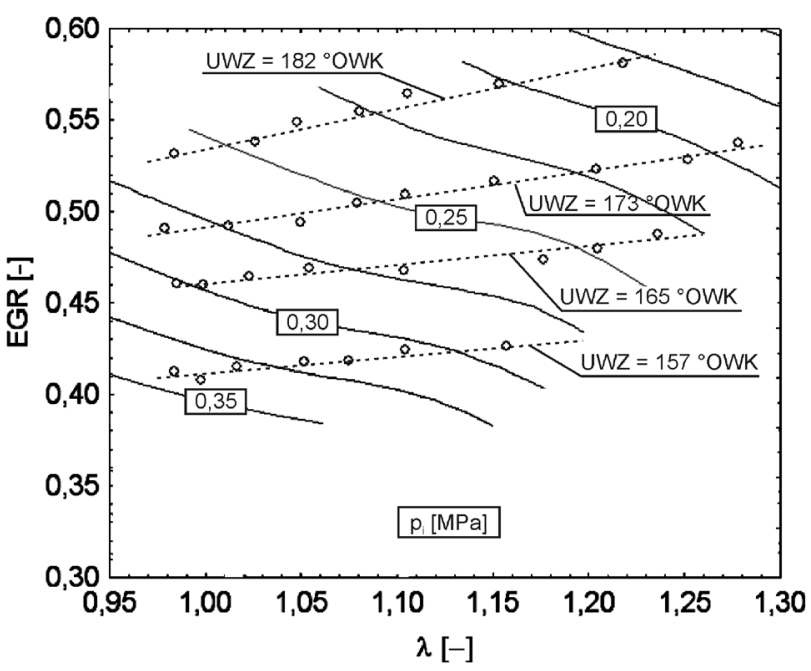

Fig. 1. Mean indicated pressure $\left(\mathrm{p}_{\mathrm{i}}\right)$ as a function of air excess coefficient $(\lambda)$ and exhaust gas recirculation rate (EGR)

Rys. 1. Średnie ciśnienie indykowane (p) jako funkcja współczynnika nadmiaru powietrza $(\lambda) i$ wspótczynnika recyrkulacji spalin (EGR) było mierzone metodą grawimetryczną z czasem pomiaru wynoszącym $30 \mathrm{~s}$.

\section{Wyniki badań}

Na rysunku 1 przedstawiono osiągalny zakres pracy silnika przy zmiennych fazach rozrządu i współczynniku nadmiaru powietrza. Ograniczenia zakresu współczynnika recyrkulacji spalin (EGR) oraz współczynnika nadmiaru powietrza $(\lambda)$ wynikają ze składu ładunku w cylindrze i z jego właściwości termodynamicznych. Maksymalna ilość zatrzymanych spalin w cylindrze jest ograniczona ilością wody i dwutlenku węgla. Jednak wraz ze wzrostem współczynnika nadmiaru powietrza zmniejsza się stężenie wymienionych składników w spalinach. W związku z tym, im mieszanka jest uboższa, tym większa masa spalin może pozostać w cylindrze. Najmniejsze wartości współczynnika recyrkulacji spalin wynikają z konieczności doprowadzenia odpowiedniej ilości ciepła do komory spalania, co ogranicza ilość powietrza w cylindrze i obniża osiągalne obciążenia silnika. Najmniejsze obciążenia osiągnięto na poziomie $0,15 \mathrm{MPa}$ średniego ciśnienia indykowanego. Dalsze zmniejszanie obciążenia nie było możliwe ze względu na rozcieńczenie paliwa i wzrost współczynnika zmienności średniego ciśnienia indykowanego (rys. 2).

Kąt wypalenia $5 \%$ dawki paliwa przedstawiono na rysunku 3. Najwcześniejszy początek spalania zaobserwowano przy nieco ubogiej mieszance paliwowo-powietrznej i umiarkowanym współczynniku recyrkulacji spalin. Zarówno wzrost, jak i spadek ilości zatrzymanych w cylindrze spalin powodowały opóźnienie spalania. Jest oczywiste, że zmiany kąta samozapłonu są związane ze zmianami temperatury sprężania. Zachowanie to można przypisać bilansowi cieplnemu procesu wymiany ładunku. Wzrost ilości zatrzymanych spalin w cylindrze spowodował obniżenie ich temperatury, stąd entalpia mieszaniny na początku sprężania malała. Zmniejszenie współczynnika recyrkulacji

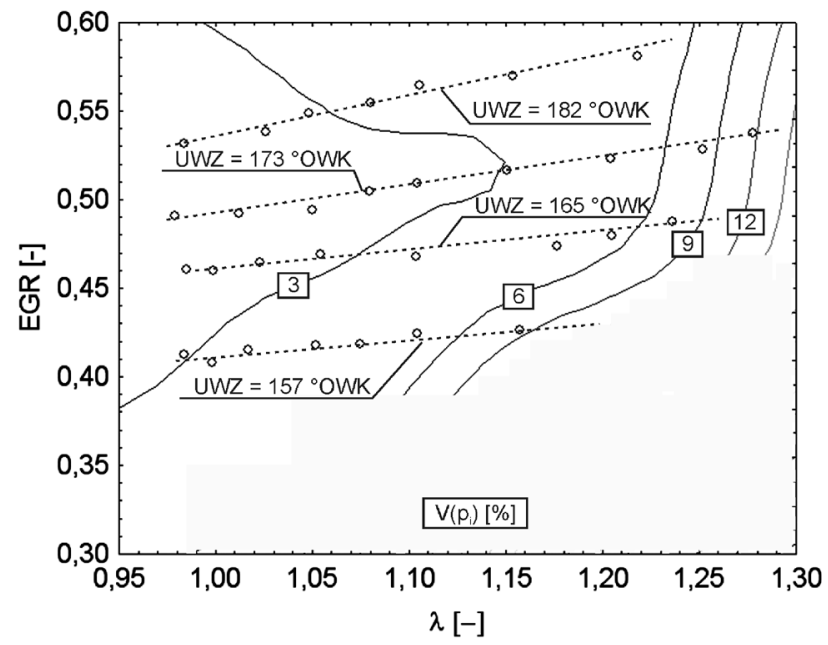

Fig. 2. Variability ratio of mean indicated pressure $\left(V\left(p_{i}\right)\right)$ as a function of air excess coefficient $(\lambda)$ and exhaust gas recirculation rate (EGR)

Rys. 2. Współczynnik zmienności średniego ciśnienia indykowanego

$\left(V\left(p_{i}\right)\right)$ jako funkcja współczynnika nadmiaru powietrza $(\lambda)$ i współczynnika recyrkulacji spalin (EGR) 


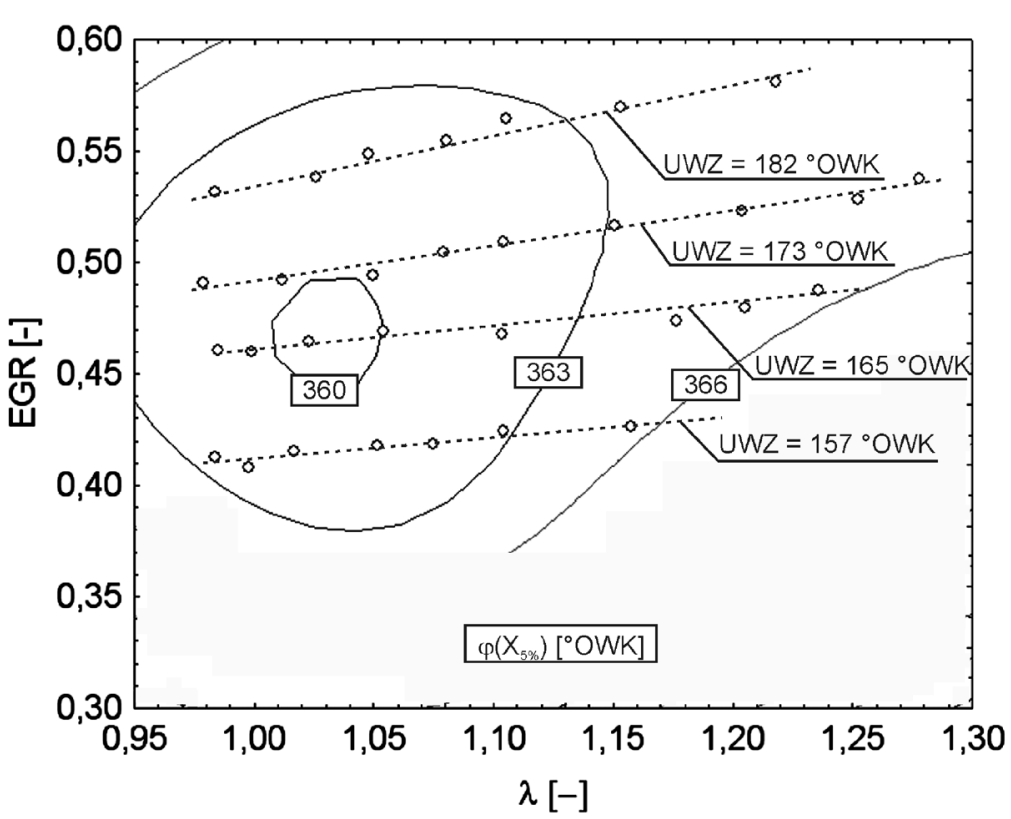

Fig. 3. The angle of combustion of $5 \%$ of fuel mass $\left(\varphi\left(X_{5 \%}\right)\right)$ as a function of air excess coefficient $(\lambda)$ and exhaust gas recirculation rate (EGR)

Rys. 3. Kąt wypalenia $5 \%$ masy paliwa $\left(\varphi\left(X_{5}\right)\right)$ jako funkcja współczynnika nadmiaru powietrza ( $\lambda$ ) oraz wspótczynnika recyrkulacji spalin (EGR)

compression temperature. This behavior may be ascribed to a thermal balance of the charge exchange process. An increase in the volume of the exhaust gas retained in the cylinder caused a decrease in the exhaust gas temperature and, therefore, the enthalpy of the mixture at the start of the compression decreased. A decrease in the exhaust gas recirculation rate leads to an increase in the temperature at the start of the intake. However, in this case, the amount of exhaust gas recirculated decreases and the amount of intake air increases, which results in a cooling of the mixture.

In order to explain the phenomena connected with the course of the charge exchange, temperature values in the cylinder at the start and end of the air intake process were determined. The calculations of the temperature during the charge exchange, as made based on the pressure in the cylinder for low-pressure values could lead to estimation errors. Therefore, the experiment was supplemented by zero-dimensional modeling of the engine operation cycle. BOOST software manufactured by AVL was used for the simulation calculations. Figure 4 presents an example of the pressure course in the cylinder as derived from the measurements and modeling. The calculations were made for the same engine operating conditions as in the case of experimental tests, where Wiebe function ratios derived from the analysis of the experimental research. Additionally, they simulated valve settings, for which the engine operation was not attainable. spalin prowadzi do wzrostu temperatury na początku dolotu. Jednak wtedy zmniejsza się ilość recyrkulowanych spalin i ulega zwiększeniu ilość zasysanego powietrza, co skutkuje schłodzeniem mieszaniny.

Aby wyjaśnić zjawiska związane z przebiegiem wymiany ładunku, określono wartości temperatury w cylindrze na początku oraz na końcu procesu dolotu powietrza. Obliczenia temperatury $\mathrm{w}$ czasie wymiany ładunku na podstawie ciśnienia w cylindrze przy niskich jego wartościach mogłyby prowadzić do błędów oszacowań. Dlatego eksperyment uzupełniono przez zerowymiarowe modelowanie cyklu pracy silnika. Do obliczeń symulacyjnych wykorzystano oprogramowanie BOOST firmy AVL. Przykład przebiegu ciśnienia w cylindrze pochodzący z pomiaru oraz modelowania przedstawiono na rysunku 4. Obliczenia wykonano dla takich samych warunków pracy silnika jak podczas badań eksperymentalnych, gdzie współczynniki funkcji Wiebego pochodziły z analizy badań eksperymentalnych. Dodatkowo symulowano ustawienia układu rozrządu, przy których praca silnika nie była osiągalna.

Na rysunku 5 przedstawiono temperaturę w cylindrze w chwili otwarcia zaworu dolotowego. Największe wartości występują w zakresie mieszanek lekko ubogich i przy najmniejszym kącie ujemnego współotwarcia zaworów (UWZ) stosowanym podczas badań eksperymentalnych, wynoszącym $157^{\circ} \mathrm{OWK}$. Przy mniejszych kątach ujemnego współotwarcia zaworów praca silnika nie była możliwa. Wyniki obliczeń symulacyjnych ukazały, że dalsze zmniejszanie ilości recyrkulowanych spalin powoduje obniżenie temperatury początku dolotu. Pomimo iż temperatura spalin wzrasta, to temperatura początku dolotu ulega obniżeniu. Wynika to ze

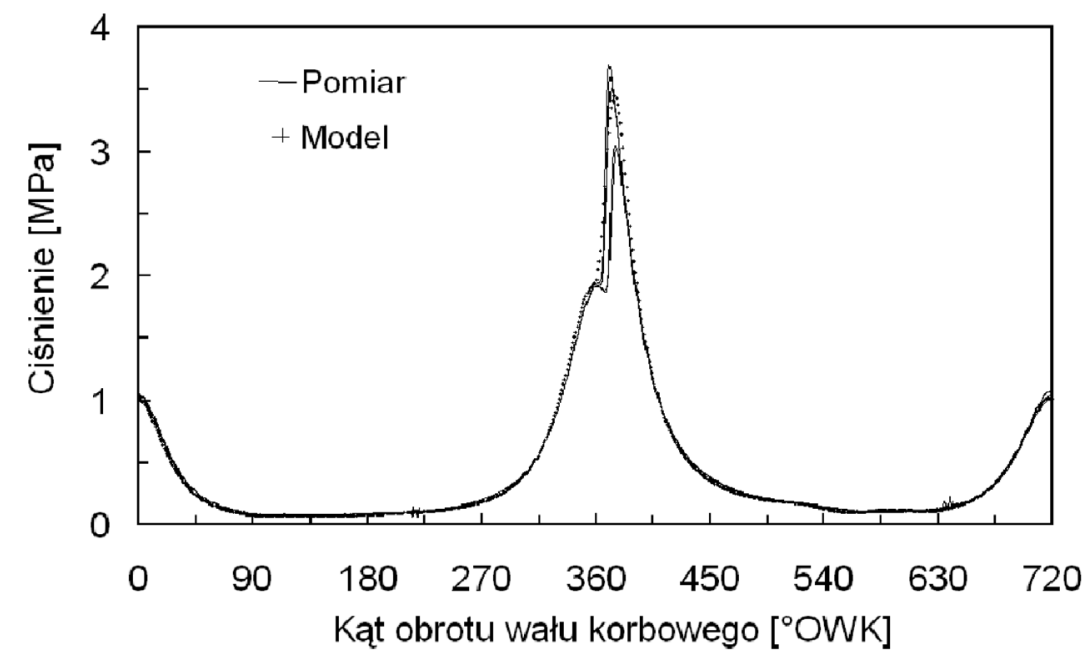

Fig. 4. Pressure in the cylinder measured within several cycles and calculated with the use of a mathematical model; mean indicated pressure of $0.34 \mathrm{MPa}$

Rys. 4. Ciśnienie w cylindrze zmierzone $w$ ciagu kilku cykli oraz obliczone za pomoca modelu matematycznego; średnie ciśnienie indykowane 0,34 MPa 


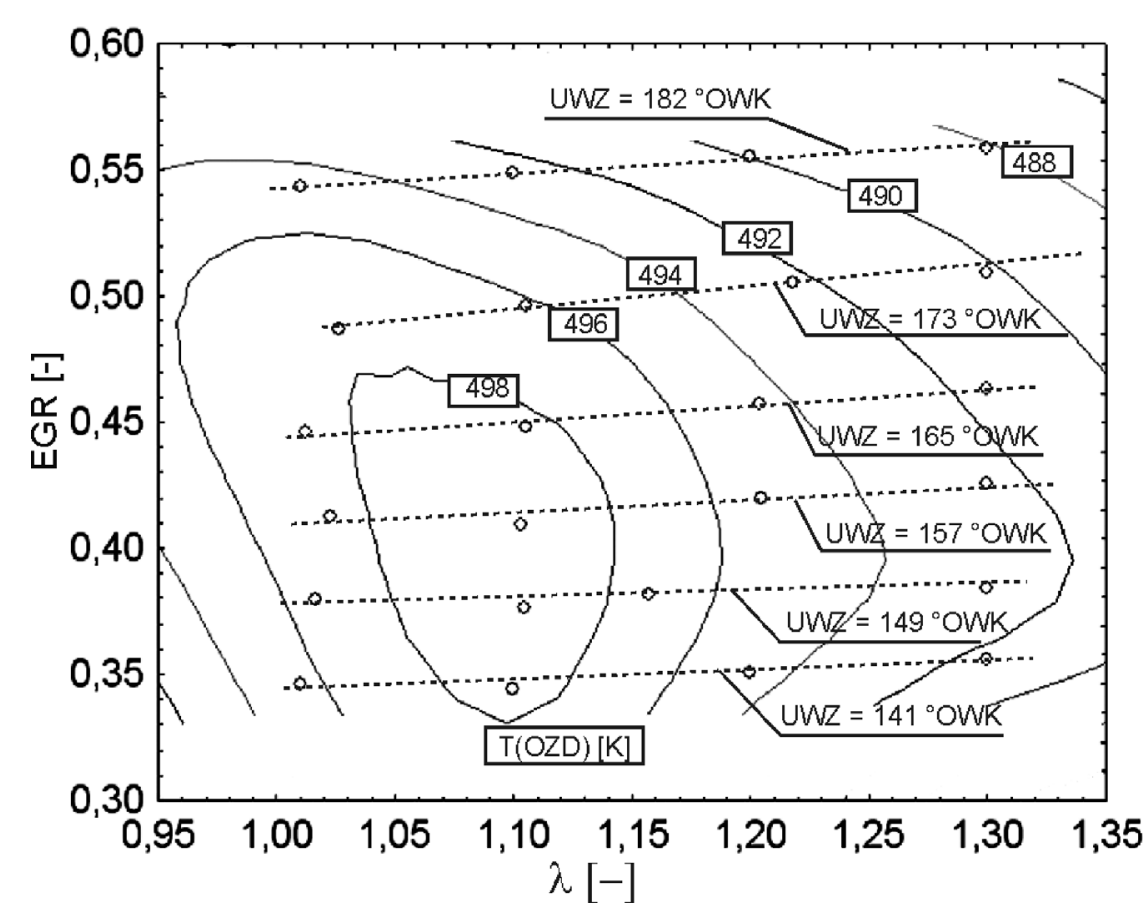

Fig. 5. Temperature calculated as at the opening of the intake valve (T(IVO)) as a function of air excess coefficient $(\lambda)$ and exhaust gas recirculation rate (EGR)

Rys. 5. Obliczona temperatura w chwili otwarcia zaworu dolotowego (T(OZD)) jako funkcja współczynnika nadmiaru powietrza ( $\lambda$ ) i współczynnika recyrkulacji spalin (EGR)

Fig. 5 presents the temperature in the cylinder as at the intake valve opening. The highest values are found in the range of slightly lean mixtures and for the smallest angle of negative valve overlap used during experimental tests equaling $157^{\circ} \mathrm{C}$.A. The engine operation was not possible for smaller angles of negative valve overlap. Simulation calculation results showed that further increase of the amounts of recirculated exhaust gas caused a decrease in the temperature at the start of intake. This results from an increased share of the thermal losses during negative valve overlap and little amount of hot exhaust gas recirculated.

The maximum values of the temperature of intake valve closing (Fig. 6) are found within the exhaust gas recirculation rate and air excess coefficient close to values for which the earliest angle of self-ignition (Fig. 3) was observed. However, experimental test results showed that the earliest self-ignition occurs for slightly lower amounts of recirculated exhaust gas than the range for which the temperature of start of the compression is maximum. An increase in the angle of negative valve overlap causes a decrease in the thermodynamic compression ratio. Moreover, considerable amount of exhaust gas in the mixture leads to a decrease in the heat capacity ratio, which also results in a decrease in the temperature of the end of compression. zwiększonego udziału strat cieplnych w czasie ujemnego współotwarcia zaworów przy małej ilości recyrkulowanych gorących spalin.

Maksymalne wartości temperatury zamknięcia zaworu dolotowego (rys. 6) występują w zakresie współczynnika recyrkulacji spalin oraz współczynnika nadmiaru powietrza zbliżonych do tych, przy których zaobserwowano najwcześniejszy kąt samozapłonu (rys. 3). Wyniki badań eksperymentalnych wykazały jednak, że najwcześniejszy samozapłon występuje przy nieco mniejszych ilościach recyrkulowanych spalin, niż zakres, w którym występuje maksimum temperatury początku sprężania. Zwiększanie kąta ujemnego współotwarcia zaworów powoduje obniżenie termodynamicznego stopnia sprężania. Ponadto znaczna ilość spalin w mieszaninie jest przyczyną zmniejszenia wykładnika adiabaty, co skutkuje także zmniejszeniem temperatury końca sprężania.

Współczynnik nadmiaru powietrza, choć determinuje temperaturę spalin, w mniej istotny sposób wpływa na temperaturę początku sprężania niż fazy rozrządu. Zmiany temperatury zatrzymywanych w cylindrze spalin kompensowane są zmianami ich gęstości. W związku z tym ulega zmianie również ilość spalin zatrzymywanych w cylindrze oraz ilość zasysanego powietrza.

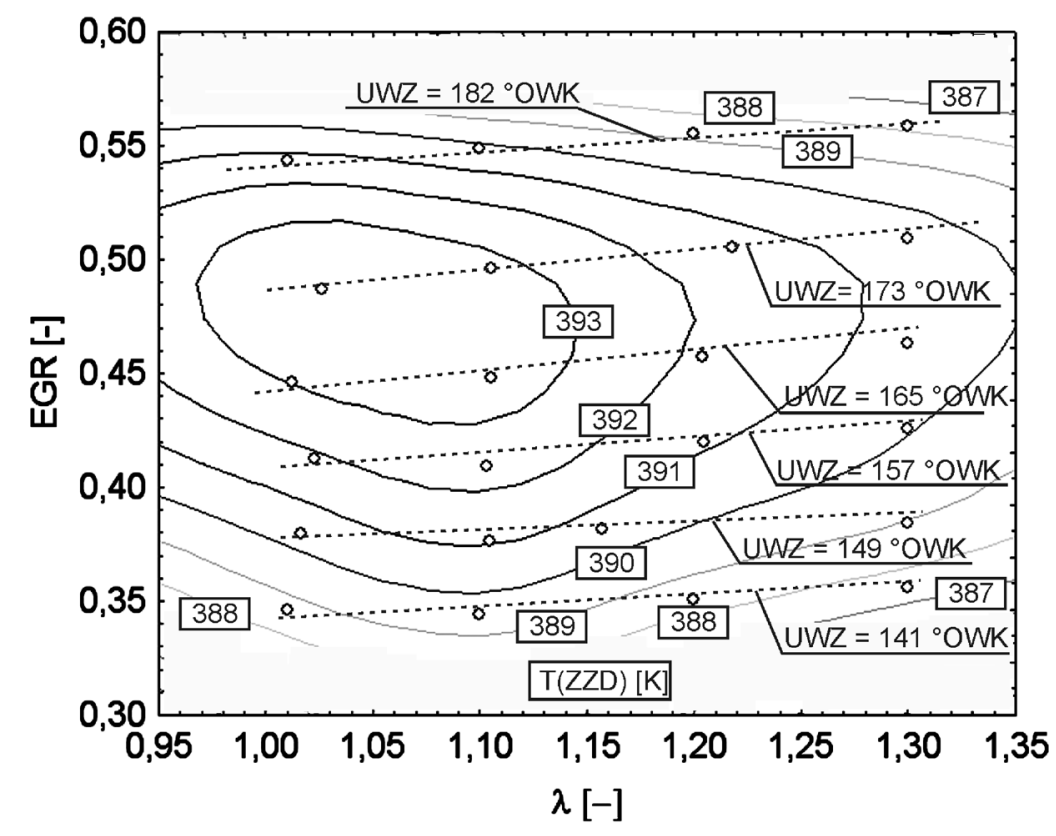

Fig. 6. Temperature calculated as at closing of the intake valve (T(IVC)) as a function of air excess coefficient $(\lambda)$ and exhaust gas recirculation rate (EGR))

Rys. 6. Obliczona temperatura w chwili zamknięcia zaworu dolotowego (T(ZZD)) jako funkcja współczynnika nadmiaru powietrza ( $\lambda$ ) i współczynnika recyrkulacji spalin (EGR) 
Although the air excess coefficient determines the exhaust gas temperature, it affects the temperature of the start of compression less significantly than the valve timing. A change in the temperatures of the exhaust gas retained in the cylinder is compensated by the changes in the density of the same. Therefore, the amount of exhaust gas retained in the cylinder and the amount of intake air also change.

\section{Conclusions}

This study presents experimental and simulation test results for a working cycle of a gasoline engine operating in the HCCI mode. The internal gas recirculation obtained from negative valve overlap was used for the increase in the temperature of the working medium. The following important conclusions result from the tests:

1. In order to enable engine operation in the HCCI mode, an equilibrium between the amount of exhaust gas retained in the cylinder, temperature of the exhaust gas and the amount and temperature of the intake air has to be maintained.

2. The attainable range of engine operation in the HCCI mode is limited by the temperature value as of closing of the intake valve (the temperature changes within a small range).

3. The temperature of the closing of the intake valve results from the energy balance of the charge exchange process. In order to maintain an appropriate course of the charge exchange, it is necessary to select appropriate valve timing and valve lifts.

\section{Wnioski}

W niniejszym opracowaniu przedstawiono wyniki badań eksperymentalnych oraz symulacyjnych cyklu roboczego benzynowego silnika pracującego w trybie HCCI. Do podniesienia temperatury czynnika roboczego wykorzystano wewnętrzną recyrkulację spalin uzyskaną dzięki ujemnemu współotwarciu zaworów. Z przeprowadzonych badań wynikają ważne wnioski:

1. Aby możliwa była praca silnika w trybie HCCI, musi być zachowana równowaga pomiędzy ilością spalin zatrzymywanych $\mathrm{w}$ cylindrze, ich temperaturą a ilością $\mathrm{i}$ temperaturą zasysanego powietrza.

2. Osiągalny zakres pracy silnika w trybie HCCI jest ograniczony wartością temperatury w chwili zamknięcia zaworu dolotowego, która zmienia się w niewielkich granicach.

3. Temperatura zamknięcia zaworu dolotowego wynika z bilansu energetycznego procesu wymiany ładunku. Aby zachować właściwy przebieg wymiany ładunku, konieczny jest odpowiedni dobór faz rozrządu oraz wzniosu zaworów.

\section{Bibliography/Literatura}

[1] Hunicz J., Kordos P.: An experimental study of fuel injection strategies in CAI gasoline engine. Experimental Thermal and Fluid Science, vol. 35, pp. 243-252, 2011.

[2] Hunicz J., Kordos P.: Experimental study of the gasoline engine operated in spark ignition and controlled auto-ignition combustion modes, SAE Technical Paper 2009-01-2667, 2009.

[3] Kozaczewski W.: Zmienne fazy rozrządu - nowe rozwiązania i silnik badawczy do badania ich wpływu. Journal of KONES Combustion Engines, vol. 8, No 3-4, pp. 182-187, 2001.

[4] Najt P., Foster D.E.: Compression-ignited homogeneous charge combustion, SAE Technical Paper 830264, 1983.

[5] Noguchi M., Tanaka Y., Tanaka T., Takeuchi Y.: A Study on gasoline engine combustion by observation of intermediate reactive products during combustion, SAE Technical Paper 790840,1979

Jacek Hunicz, DSc., DEng. - doctor in the Faculty of Mechanical Engineering at Lublin University of Technology.

Dr hab. inż. Jacek Hunicz - adiunkt na Wydziale Mechanicznym Politechniki Lubelskiej.

e-mail:j.hunicz@pollub.pl
[6] Stanglmaier R.H., Roberts Ch.E.: Homogeneous charge compression ignition (HCCI): benefits, compromises, and future engine applications, SAE Technical Paper 1999-01-3682, 1999.

[7] Wildman C., Scaringe R.J., Cheng W.K.: On the maximum pressure rise rate in boosted HCCI operation, SAE Technical Paper 2009-01-2727, 2009.

[8] Wilson T.S., Xu H., Richardson S.: An experimental study of combustion initiation and development in an optical HCCI engine, SAE Technical Paper 2005-01-2129, 2005.

[9] Yao M., Zheng Z., Liu H.: Progress and recent trends in homogeneous charge compression ignition (HCCI) engines, Progress in Energy and Combustion Science, vol. 35, pp. 398-437, 2009.

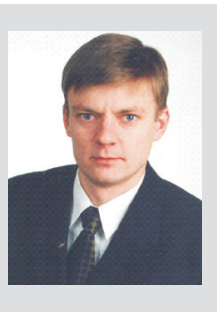

Michał Gęca, MEng. - post-graduated student in the Faculty of Mechanical Engineering at Lublin University of Technology.

Mgr inż. Michat Gęca - doktorant na Wydziale Mechanicznym Politechniki Lubelskiej.

e-mail: michal.geca@pollub.pl 